\title{
Pierre Bourdieu e a história
}

\section{Roger Chartier \\ Debate com José Sérgio Leite Lopes}

Roger Chartier: Não vou fazer hoje uma conferência formal, nem uma apresentação exaustiva da obra de Pierre Bourdieu. Gostaria de compartilhar algumas idéias ou reflexões com vocês e também sublinhar a importância do trabalho de Bourdieu segundo duas linhas. A primeira seria a contribuição de Bourdieu para a prática da sociologia cultural, da antropologia cultural e, mais ainda, em relação com a minha própria competência, a da história cultural. A partir daí, focalizaremos a atenção sobre o livro Les Règles de l'art [As Regras da arte] e também sobre Méditations Pascaliennes [Meditaçôes pascalianas], que me parece ser um dos livros mais comoventes e importantes de Bourdieu. A segunda questão que gostaria de sublinhar é a contribuição do trabalho de Pierre Bourdieu para a definição de uma dimensão histórica de todas as ciências sociais — não unicamente a história, mas também a sociologia ou a antropologia.

Começarei propondo uma leitura de As Regras da arte que pode nos ajudar a pensar como a obra de Bourdieu pôde contribuir para transformar nossas práticas de historiadores culturais. As regras da arte foi publicado em 1992, na França, livro que tem por subtítulo Gênese e estrutura do campo literário, onde há uma definição do que poderia ser uma ciência das obras culturais, como escreve Bourdieu. Esta definição se constrói em oposição a todos os postulados clássicos da crítica literária, da história da literatura, da história da arte, calcados na figura do criador incriado - ou seja, na idéia de que cada obra possui uma singularidade irredutível, na imediatez supostamente compartilhada da experiência estética ou na idéia de que há uma disposição universal ao juízo estético. Contra estes postulados, que são clássicos na tradição da história das idéias, na história das produções esté-

\footnotetext{
* Em 30 de abril de 2002, a convite do Programa de Pós-graduação em História Social da UFRJ. A transcrição deste debate foi feita por Ana Luiza Beraba e Virna Virgínia Plastino.
}

Topoi, Rio de Janeiro, mar. 2002, pp. 139-182. 
ticas, Bourdieu sublinhará dois elementos: o da necessidade de desenvolver uma sociologia genética que seja capaz de reconstruir, para cada momento histórico particular, como estas categorias ou outras foram definidas, de maneira que não sejam pensadas como universais, invariáveis, invariantes. A partir deste momento, trata-se de reintroduzir a dimensão histórica destas categorias que consideramos espontaneamente como universais, definir em que contexto, por quais razões foram estabelecidas e marcar a impossibilidade de utilizá-las retrospectivamente sem precaução e sem risco de anacronismo. A segunda questão deste livro de Bourdieu é dizer que esta sociologia genética é necessariamente uma forma de pensar relacional, um pensamento relacional. A obra, o artista, o filósofo só existem dentro de uma rede de relações visíveis ou invisíveis que definem a posição de cada um em relação à posição dos outros, ou seja, a uma posição social, em relação a uma posição estética. E me parece ser esta uma lição essencial do trabalho de Bourdieu: sempre pensar as relações que podem estar visíveis nas formas de coexistência, de sociabilidade, ou de relações entre indivíduos, ou ainda de relaçôes mais abstratas, mais estruturais, que organizam o campo - conceito essencial, nesse sentido - da produção estética, filosófica, cultural, num momento e num lugar dados. Os campos, segundo Bourdieu, têm suas próprias regras, princípios e hierarquias. São definidos a partir dos conflitos e das tensões no que diz respeito à sua própria delimitação e constituídos por redes de relações ou de oposições entre os atores sociais que são seus membros. Neste livro - e tomo este livro como exemplar dentre muitos textos de Bourdieu -, a idéia do pensamento relacional permite, ao mesmo tempo, repelir a idéia do indivíduo isolado, do gênio singular e também a idéia de uma universalidade das categorias que espontaneamente se utilizam para pensar, discutir, qualificar as obras intelectuais ou estéticas.

Há uma segunda questão importante, que é a reflexão sobre o conceito de campo. Leu-se muitas vezes a obra de Bourdieu como uma obra que representava uma forma última de marxismo, quer dizer, de uma análise das determinações sociais que definem as posturas ideológicas ou as produções simbólicas. E me parece que as coisas são mais sutis, pois há em Bourdieu, por um lado, a repulsa de uma perspectiva idealista onde as cria- 
ções estéticas não possuem raízes, mas há ao mesmo tempo, uma repulsa de uma maneira simples de pensar o determinismo social, como se houvesse uma adequação imediata entre a escolha de uma estética ou um enunciado ideológico e a posição social do artista, do escritor, do pensador ou do indivíduo. E o conceito de campo é justamente o conceito que se introduz entre as determinações sócio-econômicas na definição mais tradicional da sociologia, da história social e a produção simbólica de idéias ou de obras. Porque, como demonstra Bourdieu, há em cada campo princípios de organização que são próprios deste campo. E neste livro, refletindo sobre o que é específico nos campos culturais - estético, literário, filosófico, intelectual —, sublinhava duas características. A primeira é que os campos culturais devem ser considerados como um mundo econômico invertido. Existe uma economia da produção simbólica, mas uma economia que funciona com parâmetros opostos ao funcionamento do campo econômico. Ou seja, há uma inversão dos valores ou dos interesses que regem o campo econômico dentro dos campos culturais; por exemplo, há o desinteresse estético ou intelectual contra a busca de benefício, de lucro econômico; a gratuidade do gesto contra a utilidade da produção; a arte pela arte contra a circulação e a acumulação do dinheiro. Em segundo lugar, estes campos culturais se fundamentam numa capacidade de reflexão, de auto-reflexão, de consciência de si. Os campos culturais - por exemplo, o campo literário ou o campo filosófico - caraterizam-se pela incorporação, em cada momento histórico destes campos, de sua própria história, a partir dos diversos tipos de relação que os criadores, os produtores estéticos ou intelectuais, num dado momento do tempo, têm com o passado do campo, disciplina ou prática. Pode ser uma relação de repulsa e ruptura, como as revoluções estéticas; pode ser uma relação de paródia, como é o caso, por exemplo, de Dom Quixote; pode ser uma relação de recuperação e de integração do passado dentro do presente, um pouco como numa estética kitsch, em que há uma pluralidade de relações do presente com o passado, no campo intelectual ou no campo cultural, o que constitui um elemento chave para se compreender as diferenças entre as obras: umas jogando com a paródia, outras com a herança, outras com a repulsa e a negação etc. E é um recurso fundamental esta relação com o passado negado ou incorporado para definir a 
imposição de uma legitimidade cultural. Talvez possamos acrescentar, seguindo Bourdieu, um terceiro elemento na definição de campos culturais. Primeiro elemento: um mundo econômico que substitui o interesse econômico pelo desinteresse estético (o que não significa que não haja interesses no campo cultural, mas sim que estes interesses não são vistos a partir de uma acumulação econômica). Segundo elemento: a relação mais forte no campo cultural que em outros campos - por exemplo, o econômico — do presente com um passado de longa duração. O terceiro elemento seria o fato de que os campos culturais não são juridicamente codificados. Para entrar no campo acadêmico, por exemplo, são necessários títulos, certificados. Há uma objetividade dos títulos que permite que alguém seja considerado ou não membro de um campo acadêmico identificado com o mundo universitário. Mas no caso dos campos culturais, estéticos ou intelectuais não existem tais codificações. E a partir deste momento, para Bourdieu, o que caracterizava as lutas, os conflitos dentro destes campos era justamente a possibilidade ou a definição, a classificação de quem é considerado ou se considera como participante de um campo de criação intelectual, cultural ou estética. Neste livro, As Regras da arte, Bourdieu considera as lutas de representação, que levam ao estabelecimento de quem é digno da categoria de artista, ou de um título, como no caso do título acadêmico. Quem é artista? Quem é escritor? Quem é intelectual ou filósofo? Estes conflitos para definir esssas identidades remetem à luta pelo direito ou pelo monopólio do poder da consagração estética ou intelectual, isto é, diria Bourdieu, o monopólio do poder para dizer, como autoridade, quem está autorizado a chamar-se escritor, ou até mesmo para se designar quem é escritor e quem tem autoridade para dizer quem é escritor, artista ou filósofo. Aqui, a dimensão fundamental das tensões ou dos conflitos dentro deste espaço diz respeito aos limites destes espaços e ao direito de dizer quais são estes limites, e ao direito de dizer quem pertence a este espaço social particular. Evidentemente, segundo a posição de cada um, a definição muda. E a posição ocupada dentro do mundo social, ou dentro deste mundo particular, a definição de quem tem o direito de dizer quem é artista ou quem é filósofo se modifica, entre as definições mais acadêmicas e as definições mais espontâneas. Não se pode pensar que existe uma classifica- 
ção única e objetiva, mas sim que há uma luta de classificação, uma luta para a classificação. E um dos elementos mais essenciais do trabalho de Bourdieu era pensar que as lutas de classe, que regem e organizam o mundo sócio-econômico sempre se traduziam em ou se nutriam das lutas de classificação — o direito de dizer a sua própria identidade ou a do outro. E, segundo o poder de cada um, este direito é mais ou menos forte e a ordem que está definida a partir da posição de dominante e de dominado, dentro da luta de classificação, muda. Desta maneira, vemos que a relação entre as propriedades sociais dos artistas ou intelectuais e a identidade estética ou intelectual e as obras sempre é mediada por esta especificidade, esta originalidade do campo, do espaço social no qual se situam as produções simbólicas. E para mostrar como se pode ler Bourdieu e refletir com ele inclusive para não abordar necessariamente os mesmos temas que ele abordou - gostaria de mostrar como para a reflexão dos historiadores que tratam da cultura particularmente escrita e literária dos séculos XVI e XVII, este livro pôde modificar nossa visão tradicional. Porque em As Regras da arte, Bourdieu quis mostrar que o campo literário no seu sentido mais autônomo surgiu no século XIX. E que o campo literário - no sentido de um campo que tinha uma autonomia forte na sua relação com o mundo social global - aparecia com o surgimento da figura de um criador sem limites, de um artista todo poderoso ou de uma relação puramente estética. E é a razão pela qual uma primeira parte do livro foi dedicada ao comentário de Flaubert, assim como o trabalho sobre Manet que Bourdieu levou a cabo nos últimos anos de sua vida, infelizmente muito breve. Parece haver um paralelo possível entre a arte pela arte dentro da literatura, tal como o exemplifica Flaubert, e uma forma de criação pictórica paralela, com artistas como Manet. E se há um vínculo entre estas figuras, Flaubert e Manet, e a idéia da autonomia do campo literário ou artístico no século XIX, é porque, dizia Bourdieu, tanto Flaubert quanto Manet haviam imposto uma definição do artista sem dependências, começando com a ausência de dependência econômica, o que, num certo sentido, permite pensar um campo a partir de suas próprias propriedades. E a ruptura, a autonomia do campo, resultava, para Bourdieu, desse intenso esforço da parte de alguns criadores para romper com as formas de dependência social e 
econômica. Daí, uma pergunta que, imagino, podemos reivindicar para muitos aspectos da obra de Bourdieu: como pensar o espaço de criação literária antes da constituição da autonomia do campo ? Como se pode designar esse espaço de criação frente à existência de um campo constituído como tal, como afirma Bourdieu para o campo literário no século XIX ? E este não era o objeto de sua reflexão, mas, ao mesmo tempo, a idéia de Bourdieu leva a pensar que não havia uma espécie de linha sem descontinuidades que conduzia a esta autonomia e que não se pode pensar a criação desses espaços como um desenvolvimento contínuo ou progressivo. Para ele, havia dois mecanismos que devemos estudar e talvez projetar, retrospectivamente, no passado. O primeiro elemento é a relação entre a concepção estética das obras como produto de uma criação original, singular e individual, ou seja, a subjetividade da obra como categoria fundamental e com as noções que acompanham essas idéias: imaginação, originalidade, gênio. E a relação entre esta definição das obras, a partir deste elemento de individualização extrema, e por outro lado a remuneração, o valor comercial, a apropriação monetária, a localização das obras dentro do mercado. Quando Bourdieu olhava para o século XIX, insistia sobre a desvinculação destes dois elementos. Artistas como Flaubert, ou eventualmente como Manet, que repeliam a definição, a determinação, a dependência econômica, faziam-no porque desvinculavam totalmente a produção estética de uma remuneração monetária, o que significava que podiam viver de seus próprios recursos, sem depender do mercado das obras. É a posição pura, estética, da arte pela arte, em que não se espera e em que, inclusive, se rechaça o lucro da circulação das obras. Necessitava-se de outro tipo de recurso: o dinheiro herdado, a fortuna familiar, o ingresso de algum tipo de renda. É paradoxal dizer que as formas mais clássicas de existência econômica eram as condições de possibilidade da proposta estética mais inovadora. No entanto, no campo literário do século XIX - a literatura industrial, como se dizia, quer dizer, a literatura que permitia aos seus autores obterem uma vantagem econômica, dando-lhes a possibilidade de viverem às custas de seus escritos - era o setor menos inovador, menos original. E esta remuneração monetária pela escrita era a que alimentava a literatura de grande difusão, muitas vezes anônima, e todas as empresas de livraria, de edição, 
anunciando, no século XIX, os mass media do XX. Mas, para um historiador, é claro que esta descrição do século XIX, que é muito original, permite ao mesmo tempo refletir sobre o passado de um modo um pouco diferente. Aqui também podemos encontrar uma descontinuidade: a fundação da propriedade literária, no século XVIII, ou a emergência de figuras, de artistas, pintores por exemplo, no século XVII, que afirmam a individualização da obra, as categorias da singularidade, da originalidade, do gênio, quando então essas obras se vinculavam estreitamente com a remuneração monetária, com a idéia de uma equivalência monetária. Isso pode ser verificado através de trabalhos que foram feitos tendo por referência a obra de Bourdieu, por exemplo. Os livros de uma colega norte americana, Svetlana Alpers, sobre Rembrandt, ou os trabalhos sobre Rubens, no século XVII, mostram que, em ambos os casos, particularmente no de Rembrandt, há esta afirmação - talvez paradoxal do ponto de vista do século XIX — de uma pintura que é uma pintura do eu. Como nos autoretratos múltiplos de Rembrandt, há a idéia de que sua singularidade estética deveria ser reconhecida em cada um de seus quadros e de que há uma autonomia do valor pictórico que não se pode reduzir ao valor, por exemplo, do material que o pintor utiliza. E, ao mesmo tempo, Rembrandt era o primeiro pintor que considerava que suas obras deveriam conquistar o mercado, que afirmava o seu valor econômico e que utilizava, por exemplo, seus quadros para pagar dívidas. Quer dizer, havia um sistema de equivalência absoluta entre a obra, com os critérios de singularidade e de originalidade, e a circulação monetária e os valores econômicos. É esta relação, tão forte para um artista como Rembrandt, que o XIX desvincula. E desta maneira devemos pensar que a pré-história do campo literário e estético, tal como o descreve Bourdieu, remete-nos a configurações diferentes das que dominam o campo literário do XIX. E se pensarmos na criação literária no século XVIII, é claro que também funciona este modelo de Rembrandt. Assim, encontrava-se afirmada, por um lado, a singularidade, a originalidade das obras, porque cada texto literário, por exemplo, veicula sentimentos ou usos da linguagem, algo do indivíduo que é absolutamente irredutível. Por outro lado, devia conduzir — como diria Diderot em um texto famoso, a carta sobre liberdade de imprensa — à possibilidade do 
escritor viver de sua pluma. Isso quer dizer que havia também a idéia de que, justamente porque a obra expressava o mais singular do indivíduo, devia proporcionar a remuneração monetária, uma vez que, como a teoria do direito natural de Locke afirmava, o indivíduo é proprietário de seu corpo e por consequiência, proprietário do resultado do seu trabalho. As composiçóes literárias sendo resultado de um trabalho, o autor é o proprietário primordial de sua obra e pode legitimamente receber um benefício, uma remuneração por este trabalho. Vemos que este é um exemplo de como podemos articular, de uma maneira diferente, na primeira Idade Moderna, os elementos que Bourdieu descreve como desvinculados para forjar uma definição de campo artístico e literário no século XIX. Outra possibilidade de pensar com este livro e com o que queria ilustrar - e tenho certeza de que José Sérgio Leite Lopes concorda com isto - é a idéia de que devemos ler Bourdieu e podemos comentar Bourdieu, e explicar a dificuldade do seu estilo e de sua conceitualização. Mas o mais importante é trabalhar com Bourdieu, quer dizer, é utilizá-lo para temas que não pôde abordar, para períodos que não foram historicamente os mais importantes para ele. Trabalhar com seus conceitos, mas ir além, trabalhar com as suas perspectivas, com a idéia de um pensamento relacional e a repulsa à projeção universal de categorias historicamente definidas. Aqui, dentro do tema que estou discutindo, como pensar a relação de dependência ou autonomia nos séculos da primeira modernidade, XVI, XVII, XVIII, nos quais o mais fundamental é a presença do poder monárquico ou principesco? Como devemos pensar esta relação entre o espaço de criação estética e as formas de exercício do poder? Há diversas possibilidades. Uma delas é pensar que aparece, no século XVII, com o mundo das academias — que talvez sejam menos dependentes do poder do que pensavam - uma prefiguração de uma autonomia do espaço literário. Neste caso, haveria uma primeira definição da figura do escritor e do campo da literatura. Era um pouco o tema de um colega francês que trabalhou com Bourdieu, Alain Viala, num livro chamado La Naissance de l'écrivain [O Nascimento do escritor], e que se dedica a compreender como a construção de instituições literárias no séculos XVII — que foram, inclusive, inicialmente sugeridas pelo poder estatal — havia definido uma figura de escritor com autonomia. Ou devemos pensar que, 
ao contrário, paradoxalmente, é porque a escrita se situa dentro do âmbito do poder que pode adquirir uma certa autonomia, não constituindo uma distância contra o poder. Seria, paradoxalmente, uma produção de uma autonomia a partir de uma dependência em relação ao poder. Podem ilustrar isto - o que é uma outra maneira de trabalhar com Bourdieu — todos os trabalhos que se dedicaram, nos últimos anos, à sociologia da arte — não unicamente os que evocaram Rubens e Rembrandt, mas os que se dedicaram a pensar como se organizou a relação entre a inscrição dos pintores dentro do mundo gremial das corporações medievais ou renascentistas e como, para subtrair-se às regras, foram forjados os procedimentos e o status que davam à pintura seu pertencimento ao mundo das corporações de oficio. Eles mostram que a única saída, nesse caso, era — salvo o caso de Rembrandt - entrar no mundo das cortes. Ou seja, a dependência em relação ao Príncipe podia assegurar uma distância em relação ao mundo das corporações ou dos grêmios e assegurar à prática pictórica o estatuto de uma arte liberal, e não mais o estatuto de uma arte mecânica, como nos grêmios de ofícios. Vê-se que isso se dá paralelamente à idéia da literatura no século XVII, quer dizer, a idéia de uma dependência que produz uma autonomia, pelo menos relativa - meu amigo e colega Christian Jouhaud, num livro recente sobre poder e literatura no século XVII, que se opõe à visão de Alain Viala, sustenta a tese de que é possível se pensar que, quase no mesmo momento, fins do século XVI, começo do XVII, também houve esta autonomia conquistada através de uma nova forma de dependência que permite quebrar as coações que vinham do mundo tradicional das artes mecânicas e dos grêmios ou corporações.

Em As regras da arte há, ao mesmo tempo, uma construção teórica que propóe conceitos para aproximar-se das obras culturais; mas há a primeira parte do livro, dedicada a uma análise específica de uma obra, L'Éducation sentimentale [A Educação sentimental], de Flaubert. Desta maneira, a proposta, ao mesmo tempo teórica e empírica, analítica, permite construir elementos que podem ser reutilizados para pensar situações ou configurações históricas muito diferentes das que Bourdieu definiu como campo já constituído na sua autonomia cristalizada. Este é um primeiro elemento de reflexão que permite pensar que não podemos destacar o trabalho de Bourdieu 
de outros publicados em suas coleções ou em sua revista, Actes de la Recherche en Science Sociale. Muitos trabalhos que evocaram o campo da história da arte foram publicados primeiro como artigos e ensaios em Actes de la recherche, e depois se transformaram em livros. Isso mostra também que existe a possibilidade de um trabalho com Bourdieu que não é simplesmente a reprodução de sua teoria, mas que existe a capacidade de uma inovação proposta pelos seus instrumentos teóricos, analíticos e críticos. O segundo elemento que gostaria de sublinhar, pode ser pensado a partir de uma citação de Bourdieu muito simples: "Il n'y a pas d'au-delà de l'histoire" ["Não há nada para além da história”]. O que Bourdieu quis indicar com isso, foi uma dimensão histórica fundamental em todas as ciências sociais, inclusive, é claro, na sociologia. Daí a proximidade entre a obra de Bourdieu e uma obra que também permitiu conhecê-lo melhor na França - que me parecia talvez um pouco mais rudimentar teoricamente do que a dele, na definição de um conceito como o de habitus - que é a obra de Norbert Elias. E o que há de comum entre a obra de Elias e a de Bourdieu é considerar que a sociologia não se define como uma ciência social do presente, o que Elias chamou de "o retiro do sociólogo no presente" [The Retreat of Sociologists into the Present ${ }^{1}$ ], como se o objeto da sociologia fosse a sociedade contemporânea. Nem para Bourdieu, nem para Elias este projeto era válido, e a sociologia não se definia por um recorte cronológico particular. Era uma maneira de pensar o mundo social. E Bourdieu foi quem multiplicou as pesquisas sociológicas sobre a França contemporânea. Dedicou muito de seus livros ao século XIX, porque parecia um momento de cristalização dos campos culturais, e foi inspirado por muitos trabalhos sobre a Idade Moderna. Desta maneira, existe uma idéia da sociologia — fiel à fundação da sociologia na França por Émile Durkheim ou por Marcel Mauss - com uma tripla dimensão: sociológica, em suas técnicas e conceitualizações; antropológica, em suas descrições; e histórica, em suas perspectivas. A partir deste momento, se pode entender a relação de Bourdieu com os historiadores. Com a maioria dos historiadores, esta relação nem sempre foi fácil. Isso porque os historiadores, por um lado, têm tendência a repelir o que consideram uma conceitualização excessiva, e têm sempre a referência empírica muito forte na suas perspectivas. E, em segundo lugar, 
porque havia, com Bourdieu, um retorno a esta definição de sociologia como o saber do mundo social. Ou seja, finalmente, um saber, um conhecimento que afastava o saber histórico e a sociologia como ciência das ciências sociais. Era mais ou menos a proposta da tradição francesa. E também, a partir dos Annales e de Braudel em particular, houve a mesma tentação de definir a história como disciplina chave, que devia organizar a totalidade do campo das ciências sociais. Há artigos famosos de Braudel que dedicam-se a esta idéia da história como a ciência, o saber, o conhecimento chave, capaz de organizar a totalidade do campo das ciências sociais, em particular a partir de sua conceitualização das temporalidades. Havia uma tensão quase necessária entre os historiadores e os sociólogos, especificamente entre Bourdieu e a tradição histórica francesa. E uma das razóes disso, pareceme, é que há historiadores que trabalharam com Bourdieu — como eu mesmo - mas o mundo dos historiadores de Bourdieu era mais um mundo estrangeiro, ou ainda composto por historiadores da arte, como Carlo Ginzburg — pois Carlo Ginzburg é também um historiador da arte visto que seu livro sobre Piero de la Francesca não pode ser entendido fora da sua relação com Bourdieu. É a partir da idéia de que "não há nada para além da história", deste ponto de partida, que podemos ver como a contribuição de Bourdieu permitiu reformular, para os que podiam escutá-la e entendê-la, algumas tensões da prática dos historiadores. Nesse sentido, há uma contribuição de Bourdieu que pode ser relacionada com o que discutimos ontem, ${ }^{2}$ depois de uma pergunta feita por Andrea Daher sobre o tema do conhecimento histórico e da repulsa ao relativismo, idéia fundamental na perspectiva de Ginzburg. Diferentemente de algumas leituras de Bourdieu, há um sociologismo que define todas as coações sociais que regem uma produção estética ou científica, reduzindo essa produção à suas condições sociais e aos interesses econômicos primordialmente involvidos nesta produção. Esta é, em parte, a perspectiva que encontramos em alguns trabalhos de sociólogos da ciência. Isto é, há uma espécie de redução do saber às suas condições de produção, que finalmente desemboca num relativismo. Não era esta a posição de Bourdieu. Muito pelo contrário. A idéia de que estudar as condições sociais históricas de produção de conhecimento e manter a validade deste conhecimento e seus critérios de prova - o que 
exige uma força de adequação com seu objeto comprovada — indicam uma tensão absolutamente central. Sempre cito uma passagem do livro Raisons pratiques [Razões Práticas] em que Bourdieu diz que recordar a dimensão social das estratégias científicas não é reduzir estas demonstrações científicas unicamente a exibições retóricas. Dizer que o capital simbólico desempenha um papel de ferramenta e de aposta dentro das competições científicas não é fazer da busca do lucro simbólico o fim ou a razão de ser exclusiva das condutas científicas. E para Bourdieu, ao seu modo, usando as reflexões de alguns historiadores sobre o conhecimento histórico, havia uma prática da nova história das ciências. Havia a necessidade de pensarmos juntos o elemento de inscrição de cada produção de saber dentro de condições de possibilidade específicas e dentro de competições econômicas ou simbólicas, ao invés de abandonarmos a idéia de que havia critérios dentro deste processo que permitiam, num momento dado, validar ou não, autentificar ou não, comprovar ou não tal ou tal produção do saber. A partir daí, temos uma primeira lição de Bourdieu que pode esclarecer o debate que evocamos ontem entre, por um lado, a história como ficção - e, por consequência, sobre o relativismo - e, por outro lado, uma percepção de uma objetividade sem condições históricas fora de determinações sócioeconômicas, que pode definir uma posição positivista ou uma posição idealista. Bourdieu define muito claramente: não há contradição entre descobrir, analisar as condições de possibilidade de produção de saber e considerar que este saber pode ou não ser comprovado numa epistemologia particular em um tempo e um lugar. A segunda contribuição de Bourdieu para uma reflexão sobre a história — em geral, não unicamente a história cultural, que foi o objeto da primeira parte da minha intervenção - é a possibilidade de superar uma dicotomia, que foi reforçada nos últimos anos, entre dois posicionamentos : por um lado, o do que se pode chamar física social, quer dizer, uma história estruturalista que reconstituía, fora da percepção da consciência dos indivíduos, os laços, as dependências, as dominações que regiam, governavam suas posiçôes como dominantes ou como dominados. A física social é o que pode definir a história demográfica, social, econômica na tradição francesa dos Annales, dos anos 30 aos anos 60, e que se vinculava mais diretamente ao modelo estruturalista. E por outro 
lado, a fenomenologia social, ou seja, a história que se baseia na linguagem dos atores, nas palavras que usam, na consciência que têm, nas suas percepções, isto é, que se situa do lado de uma forma de história que não se baseia nas interdependências desconhecidas, mas nas percepções conscientes. Esta fratura pode ser encontrada em quase todas as ciências sociais, entre uma sociologia quantitativa e a etnometodologia. Ou pode também ser encontrada na economia, entre as teorias da eleição racional e a descrição dos mecanismos econômicos não percebidos pelos indivíduos. Na história, somam-se nos últimos anos as propostas da microhistória e as propostas de um retorno a um estudo das racionalidades dos atores, com as obras de historiadores que tentaram resgatar dos arquivos as próprias palavras dos indivíduos. É claro que esta tensão se tornou muito forte, e é muito difícil articular a física social das análises estruturalistas e a fenomenologia social das análises da consciência da percepção e da racionalidade dos indivíduos. E a partir daí, houve um enfrentamento estéril entre os que se mantinham fiéis a uma forma clássica de história sócio-econômica e os que se baseavam numa análise das relações e ações organizadas segundo as racionalidades explícitas dos atores. E parece-me que a contribuição de Bourdieu ajuda a superar esta tensão ou esta contradição, por sugerir que, para cada objeto de análise, devemos pensar ao mesmo tempo no espaço, no campo de coerção, de coações, de interdependências que não são percebidas pelos indivíduos, e, ao mesmo tempo, localizar dentro dessa rede de coações um espaço para o que chamava "sentido prático", ou estratégia, ou ajuste às situações - e que, inclusive, para indivíduos que têm as mesmas determinações sociais, não funciona de uma maneira homogênea. E todo um trabalho feito sobre a história dos livros, história dos textos, história da leitura, pode ilustrar ou se apoiar nesta perspectiva. Há coações, que vêm, por sua vez, das intençôes do texto, que vêm das possibilidades abertas ou fechadas pela forma de escrita de um texto, um manuscrito, um livro impresso, a tela de um computador. E há coações que vêm para cada leitor através de seu pertencimento a uma comunidade sócio-cultural. Isto quer dizer que este tipo de história deve conhecer, em primeiro lugar, uma série de determinações, de coações, que se ligam ao texto, ao objeto e ao sujeito que se apodera do texto de uma forma particular. Ao mesmo tempo, sabe- 
mos que todos os leitores, inclusive os que pertencem a uma mesma comunidade de leitura, de interpretação, à mesma comunidade sócio-cultural, à mesma classe social, não lêem da mesma maneira ou não produzem o mesmo sentido frente a uma mesma obra lida no mesmo suporte. E daí este espaço para a estratégia pessoal, individual, para uma competição mais ou menos forte dentro de coações externas ou internas compartilhadas. E muitos dos novos campos da história — os estudos sobre a cidade, os estudos sobre os processos educativos, os estudos sobre a construção dos saberes científicos, inclusive a própria história — se podem entender, tendo sido superadas as contradiçõos a partir desta perspectiva. E essa é a razão, ao que me parece, pela qual Bourdieu ajudou os historiadores a se distanciarem da herança da história das mentalidades para refletirem de uma maneira mais complexa, ou mais sutil, sobre a relação entre as determinações externas, a incorporação destas determinações e, finalmente, as ações. E é a razão pela qual o conceito de representação que Bourdieu utiliza, o conceito de classificação — de luta de representação, de luta de classificação — se tornou uma categoria essencial, porque permite instalar a análise dentro da herança da sociologia e da antropologia fundadora de Mauss e de Durkheim. E a categoria de representaçôes coletivas, tal como foi definida por Durkheim e Mauss, aponta para a incorporação, dentro do indivíduo, do mundo social a partir de sua própria posição dentro deste mundo, como se as categorias mentais fossem resultado da incorporação das divisões sociais e definissem para cada indivíduo a maneira de classificar, falar ou atuar. Um livro como La Distinction [A Distinção] se fundamenta sobre a idéia de que estas representações do mundo social, ou seja, a representação que o indivíduo ou o grupo - tem de si mesmo e a representação que tem dos outros, se traduzem através dos estilos de vida — que era o objeto da pesquisa do livro. Mostra como nas práticas de consumo, as diversas classes, os diversos grupos manifestam essas representações que tinham do mundo social, sem necessariamente organizá-las de maneira consciente. E, finalmente, para Bourdieu, a identidade social que se percebe através do que cada grupo mostra de si mesmo e que se remete à incorporação mental coletiva de esquemas de percepção, desemboca na encarnação desta identidade social através daquilo que representa este grupo de uma maneira individual ou 
coletiva. A definição do ser social, da identidade social, é dada assim não unicamente a partir das condiçóes objetivas que definem as categorias sociais, mas, como diz Bourdieu, do ser percebido por si mesmo ou pelos outros. Daí a luta constante de classificações. E daí também uma visão dinâmica do mundo social, baseada não unicamente na idéia de hierarquia, que remete a níveis desiguais do ponto de vista sócio-econômico, mas na idéia de que as representaçôes e os discursos que anunciam estas representações pertencem à construção do social. Há um recurso na obra de Bourdieu para superar uma outra dicotomia, entre os historiadores que pensam que podemos pensar o mundo social a partir unicamente de critérios objetivos, de desigualdades econômicas - a partir da posição nas relações de produção, do nível econômico, do pertencimento a um estamento ou classe socioprofissional - e os historiadores que pensam que o mundo social é produto dos discursos e que não há realidade social externa aos discursos. Este é um grande debate na historiografia norte-americana. A perspectiva de Bourdieu, parece-me, propõe, de uma forma sutil, uma relação dialética entre características objetivas que definem aquilo que, para um indivíduo, é possível enunciar, pensar, classificar - recursos estes que pertencem ao mundo das representaçóes coletivas e que se ligam diretamente à posição no mundo social. Mas, ao mesmo tempo, a expressão destas representações coletivas constantemente deslocam, inventam, no mundo social, as divisões sociais. Um livro como o de Luc Boltanski, Les Cadres [Os Executivos], num momento seguinte ao trabalho de Bourdieu, é a ilustração disso: a invenção de uma categoria social, os executivos, a partir de propriedades objetivas, mas que não eram suficientes por si só para criar o grupo. $\mathrm{O}$ grupo se criou através das representações e dos discursos que impunham aos membros destes ofícios disseminados e aos outros grupos sociais e, finalmente, ao Estado, a idéia de que existia um grupo social homogêneo, identificável a partir de seu estilo de vida — os executivos. É uma demonstração, parece-me, da pertinência desta perspectiva. Nos últimos anos, esta inspiração de Bourdieu permitiu instalar no cerne de muitas pesquisas históricas um conceito como o de violência simbólica ou de dominação simbólica. Isto é, pensar que não há unicamente, numa sociedade, formas de dominação brutais ou enfrentamentos explícitos, imediatamente sociais: 
rebeliōes, greves, afrontamentos. Para que uma dominação se reproduza, é preciso um mecanismo de violência simbólica ou de dominação simbólica. Há um livro de Bourdieu em que se utiliza mais este conceito de dominação simbólica - a idéia de que existe este tipo de dominação quando os dominados incorporaram os princípios da dominação que asseguram a sua dependência como legítima —, que é, evidentemente, o livro sobre dominação masculina. Nele, há a seguinte definição: "Os dominados utilizam as categorias construídas do ponto de vista dos dominantes sobre as relações de dominação e, a partir daí, fazem estas relações de dominação parecerem naturais." O fundamento da dominação masculina considera que ela pertence a uma ordem da natureza e que, a partir desse momento, se reproduz. Mas o importante na obra de Bourdieu era destacar que esse tipo dominação se reproduz a partir da incorporação da legitimidade do princípio da dominação nas percepções dos dominados — neste caso, das dominadas (o que é também uma possibilidade de se pensar a dominação colonial). Não se deve pensar que se instala uma dominação sem violência. Há um ato fundador da violência que é a conquista dos territórios, a dominação dos corpos, o controle dos indivíduos. Mas para reproduzir-se este tipo de dominação não há a necessidade de se manter o mesmo nível de violência explícita, mas há de se instaurar um mecanismo mais sutil que é o da incorporação da legitimidade pelos dominados da desigualdade ou da dominação. Não é justo dizer, nesse sentido, que Bourdieu nunca tratou da possível destruição da reprodução desses mecanismos: é claro que isso faz parte de sua análise, baseada nos mecanismos que asseguram a reprodução da dominação nas condições que permitem, num certo momento histórico dado, uma ruptura com esta dominação. Os dominados podem recusar progressivamente o que haviam incorporado, ou ainda, um acontecimento brutal pode dilacerar o tecido ordinário da reprodução e introduzir uma crise violenta. Entre essas duas modalidades de ruptura, Bourdieu não escolhe claramente. Observando rupturas de dominação, esperando que aconteçam, Bourdieu estava invadido ao mesmo tempo pela descrição analítica, científica e crítica da força dos mecanismos que asseguram a reprodução das dominações. Talvez seja a razão pela qual haja algo de melancólico em seu trabalho. 
E vou concluir com algo nesta linha de pensamento, sublinhando a importância do trabalho intelectual de Bourdieu, como fiz até aqui através dos seus conceitos. Isso me parece útil, porque a figura de Bourdieu teve uma presença importante na mídia e na sociedade francesa, tendo sido o único intelectual que teve com a sua morte a primeira página de muitos dos jornais, desde de Foucault, e antes, de Sartre. Isso cristalizou um sentimento forte, inclusive nas pessoas que nunca tinham lido uma só linha de Bourdieu. Um pouco como no caso de Rousseau, no século XVIII. Pensavam talvez que Bourdieu, tal como Rousseau, lhes defendesse contra esta reprodução da dominação, sem necessariamente terem conhecimento de uma obra que, exceto os últimos livros, é muito difícil. É uma obra conceitualmente complicada, e é muito difícil entrar nela. Mas restou a figura pública e a tristeza, largamente compartilhada, depois de sua morte. É claro que havia um risco nisso: esquecer que Bourdieu não era o único que se opunha à globalização, mas era um sociólogo que havia desenvolvido pesquisas muito complicadas, havia escrito livros muito difíceis e proposto análises críticas que se dedicavam a temas que não eram necessariamente os mais contemporâneos. Há mais dois aspectos a serem acrescentados. $\mathrm{O}$ primeiro constitui uma das tensões fundamentais de Bourdieu: a de que a sua própria perspectiva intelectual implicava que ele fosse, ao mesmo tempo, objeto e produtor de sua análise. O livro Homo Academicus, de 1984, que analisa um campo particular, o campo acadêmico, a que claramente Bourdieu pertenceu, consiste, nesse sentido, numa análise sociológica do espaço social no qual ele próprio se encontrava. E Bourdieu expressava no prólogo deste livro a dificuldade de constituição de qualquer discurso científico sobre o mundo social. Pensava que havia uma dificuldade em produzir um discurso analítico sobre o mundo social porque havia uma repulsa do mundo social frente a sua própria verdade — particularmente, mas não unicamente, dos dominantes. O discurso sobre o mundo social é sempre difícil porque é contrário à natureza dos interesses imediatos das desigualdades. E, desta maneira, a tarefa não é fácil — talvez seja mais fácil escrever sobre o século XV ou XVI, como eu. A dificuldade de qualquer discurso científico sobre o mundo social logra seu paroxismo, no caso de um discurso que se dedica ao espaço, ao próprio jogo no qual o seu autor se en- 
contra comprometido. E daí a tensão entre, por um lado, a reconstrução dos mecanismos desconhecidos pelos indivíduos e, por outro lado, a necessidade do sociólogo de objetivar a sua própria posição como membro, nesse caso, do campo acadêmico e, mais geralmente, do campo social. Parece estar introduzida aí uma divisão, uma tensão no indivíduo. Em minha opinião isso se remete a esta tensão fundamental: a idéia segundo a qual o sociólogo não está ausente do objeto de sua descrição. Pode-se dizer que o historiador também está dentro do seu objeto, mas não da mesma maneira. Não participamos como historiadores do campo da produção historiográfica do século XVI ou do XVII. Desta maneira, há uma presença, um compromisso, uma relação, mas que não funciona segundo o mesmo modelo. E a reflexividade crítica que implica tal posição, me parece uma das razões fundamentais da tensão e, como dizia, talvez da melancolia que Bourdieu expressa em alguns textos. Ele sempre se recusou, até os últimos anos, a escrever qualquer forma de autobiografia. Entretanto, num livro como Méditations pascaliennes [Meditaçôes Pascalianas] há muito disso. Encerrarei hoje com Pascal, com uma citação de que sempre gostei nas Meditaçôes Pascalianas, na introdução de Bourdieu: "Desde há muito, quando me faziam a pergunta, em geral mal intencionada, acerca de minhas rela com Marx, eu aquirira o hábito de responder que, tudo ponderado, e caso fosse de fato indispensável uma filiação a qualquer preço, eu me consideraria, muito mais, um pascaliano..." E por que Pascal? Seria todo um outro seminário sobre a maneira de Bourdieu ler Pascal, sobre a formulação, numa outra linguagem, do mais essencial em sua própria sociologia. E, por exemplo, o conceito de campos articulados aparecia em Pascal como a categoria de grandeza. A grandeza do rei não é a grandeza do homem de letras, que não é a grandeza do sábio, isto é, que tem interesses, proveitos, expectativas que variam segundo essas ordens de grandeza. E muitos outros elementos, como a dominação simbólica, também apareciam em Pascal. Esta formulação, para Bourdieu, era uma maneira de dialogar com o passado e, ao mesmo tempo, de desenvolver uma conceitualização própria. E, ao final das Meditações Pascalianas, há uma reflexão inesperada a respeito da relação muito forte entre o caráter insuportável do pensamento da morte e um tema tão caro a Pascal, que é o da diversão do mundo, ou seja, a busca dos 
prazeres ou das ocupações que podem distrair o homem deste pensamento fundamental da limitação da sua existência. E Bourdieu faz referência a Pascal para mostrar que havia uma exigência fundamental que ele tratava em termos de religião e que Bourdieu podia tratar em termos de construção do saber. E vou acabar com esta citação de Pascal: "Vamos morrer sós, então devemos fazer como se estivéssemos sós. Buscaríamos a verdade sem hesitar, e se a recusássemos, mostraríamos estimar mais a estima dos homens do que a busca da verdade."

José Sérgio Leite Lopes: Agradeço o convite honroso para estar aqui debatendo no Programa de Pós-graduação em História Social da UFRJ com Roger Chartier e Andrea Daher. É uma honra, porém uma tarefa difícil, porque esta já seria uma palestra em si mesma, não há necessidade de debatedor. Mas no sentido de provocar a discussão coletiva, arriscarei propor algumas questões sobre a relação de Bourdieu com a história e com os historiadores. Creio poder dizer que a temática da história teria uma importância maior na obra de Bourdieu a partir de 1980. Em que construções anteriores de Bourdieu os seus conceitos de habitus, de capital, de campo tomam uma feição mais histórica? Se tomarmos um artigo chamado Le mort saisit le vif $[\mathrm{O} \text { morto se apodera do vivo }]^{3}$ - que foi um artigo originalmente publicado em Actes de la Recherche, em 1980 —, veremos que ele propõe certas categorias para se pensar o material histórico em termos do que seria uma história incorporada pelos homens, que se apresenta com suas práticas, suas ações, seus testemunhos, sua história oral, ao lado de uma história objetivada ou reificada ou institucionalizada, que aparece em arquivos, em estátuas, em construções, na arquitetura, numa série de coisas. Enfim, ele está, a partir desse momento, mais preocupado diretamente com a história, com a presença da história nas suas análises e, a partir daí, se vê na produção da revista Actes de la Recherche, e depois nos seus próprios livros, essa busca e essa presença maior da história. Por exemplo, no artigo chamado Espace social et genèse des 'classes' [Espaço social e gềnese das 'classes' ${ }^{3}$, assim como no livro Choses dites [Coisas Ditas], Bourdieu se define como um estruturalista construtivista ou um construtivista estrutural. E, progressivamente, vai se defendendo de uma visão que se tem do Bourdieu dos anos anteriores, quando ele inicia a sua produção, nos anos 
60 e 70, do estereótipo de um estruturalista reprodutivista. Bourdieu teve uma formação filosófica na École Normale Supérieure, essa instituição francesa poderosa no campo intelectual e educacional. Tem, portanto, essa bagagem de filósofo, em particular da história da ciência e da filosofia, que era uma das vertentes das alternativas filosóficas, no momento da sua formação. Por um imprevisto da vida, digamos assim, foi convocado para o serviço militar na Argélia, e a sua trajetória é infletida por este acontecimento histórico. Então, ele se torna etnólogo e sociólogo, desvia-se pela antropologia e pela sociologia, para o estudo das realidades sociais colocadas pelo impacto da guerra colonial que estava presenciando como convocado, porém com funções técnicas. Tendo ligação com a universidade local, ele aproveita essa situação para fazer pesquisa. Com a formação que tem, sua primeira produção etnológica foi influenciada pelo estruturalismo da época, pela obra de Lévi Strauss que é uma importante inspiração para ele nesse momento. Vê-se na sua produção, na Argélia, um diálogo muito grande com a estatística e com os estatísticos. A sua participação é mais como etnólogo, como então se afirma, porém já com um diálogo muito grande com a estatística. Um dos seus primeiros livros, Travail et travailleurs en Algérie ${ }^{5}$ [Trabalho e trabalhadores na Argélia], é feito em colaboração com três estatísticos, que estabelecem dados numéricos sobre o trabalho e o desemprego na Argélia ao lado de uma análise sociológica de Bourdieu sobre os trabalhadores e suas concepções de trabalho. Embora este seja um trabalho em que ele pode ser visto retrospectivamente como "construtivista", há várias influências e várias vertentes na sua produção, inclusive uma vertente como etnólogo estruturalista. Alguns artigos marcam este caráter, como por exemplo, a análise de La Maison kabyle [A Casa cabilia], ${ }^{6}$ publicada numa coletânea em homenagem aos 60 de Lévi-Strauss. Ao mesmo tempo, após essa passagem pela Argélia, ele procura fazer uma análise de sua própria origem social. De fato, Bourdieu vem de uma comunidade camponesa, e tem assim uma origem social sui generis em termos de um acadêmico, de um universitário. A explicitação do peso de sua origem em toda sua vida e obra ocorreu perto de sua aposentadoria e em textos póstumos, especialmente num texto intitulado Esquisse pour une auto-analyse [Esboço para uma auto-análise]. ${ }^{7}$ Pelo fato dessa origem, foi aluno bolsista até o fim 
da trajetória universitária, e pôde se tornar um professor universitário. E ele então, confrontado com os camponeses da Argélia, procura "fazer um teste" - pelo menos é a racionalização que ele mesmo faz — com os camponeses que conhecia da sua infância. Procurou fazer o contrário de Tristes Trópicos - como ele mesmo conta em filmes recentes, como La Sociologie est un sport de combat [A Sociologia é um esporte de combate], de Pierre Carles, de 2001, ou na entrevista dada a Andrea Loyola para a UTV da UERJ. Ao invés de fazer uma viagem longínqua, naqueles países longínquos - quer dizer, por aqui mesmo - ele devia procurar perto, no familiar. Mas não se trata de um familiar tão familiar assim para quem é professor universitário. A sua origem não é uma das mais modais, das mais freqüentes e permitiu esse trabalho. Quando se olha a posteriori, é um trabalho muito objetivo, muito carregado de observações, de fotos, de estatísticas e muitos depoimentos, de genealogias, um estudo da reprodução do patrimônio entre as famílias camponesas. E, em nenhum momento, Bourdieu diz que é a sua própria vizinhança, sua família, sua origem que está ali. Posteriormente, disse que fez essa viagem para o familiar, mas não há nenhuma explicitação maior. Agora foi publicado postumamente um livro chamado Le Bal des célibataires [O Baile dos celibatários], baseado no artigo que se chama Celibato e condição camponesa, ${ }^{8}$ onde a atenção toda é voltada para as impressões e intuições que o levaram a fazer a pesquisa, que foi a observação do baile em que os solteiros ficavam à parte, não tinham par. E ele mesmo diz que, na época, não fora capaz de se abrir e dizer que, por exemplo, o pai dele foi freqüentemente fazer as entrevistas com ele. O próprio pai era um informante e era também uma garantia para a sua entrada no grupo, coisas desse tipo. Então ele tinha uma concepção mais objetivista: estava estabelecendo uma ruptura científica pela objetivação dos outros e de si mesmo, mas era, antes de tudo, uma grande ruptura objetivista. E, com uma fúria de trabalho e de pesquisa, encara uma série de objetos, tanto pelo lado etnológico, na Argélia, como na sociologia da França. Quando volta para a França, começa a fazer trabalhos na área da educação, da cultura, de onde vem o livro Les Héritiers [Os Herdeiros], depois La Reproduction [A Reprodução], e outros livros, como L'Amour de l'art [O Amor à arte], que é uma pesquisa sobre os museus, e Un art moyen [Uma arte média], sobre a foto- 
grafia. Trata-se, por um lado, de uma série de pesquisas sobre o ensino, sobre a universidade, os estudantes e a reprodução pedagógica e, por outro lado, o acesso à cultura erudita, aos museus, e uma forma média de cultura que seria a difusão da fotografia. Ele estabelece uma série de pesquisas também, nessa ânsia de objetivação com aparato estatístico, com questionários extensivos. Portanto, se estabelece como um autor da sociologia do presente, da etnologia argelina, onde a política está presente, imbricada, embora tivesse tido uma posição de que a política se exerce através do exercício da ciência, da pesquisa e da revelação da realidade social. Mais tarde, Bourdieu tem outro encontro com a história, ao estudar o sistema educacional universitário, e quatro anos depois do livro Les Héritiers. Les Étudiants et la culture [Os Herdeiros. Os Estudantes e a cultura] ser publicado, acontece uma grande transformação desse sistema, em maio de 1968. Então, apesar de suas obras procurarem os próprios acontecimentos históricos, aquilo que ele produz é uma análise objetivada daquele presente, com um aparato estatístico forte, com análises do campo - progressivamente ele vai estabelecendo o seu conceito de campo. Isso culmina, em 1970, com o livro $A$ Reprodução, que depois é traduzido nos Estados Unidos, e no Brasil, em 1975. Nesse momento, Bourdieu tem fama de sociólogo estruturalista, ao mesmo tempo com pouco uso da história e com essa ênfase nos mecanismos de reprodução, como uma visão da dominação de cima para baixo, desde o centro da dominação, razão pela qual foi criticado constantemente. Posteriormente, Bourdieu deixa claro que tinha incorporado esse arsenal da análise estrutural e que, no entanto, estava atento ao agenciamento social, à transformação histórica, através de uma crítica interna que fez ao estruturalismo, através do conceito de habitus e dessa passagem das regras de parentesco às estratégias matrimoniais, dessa busca da prática, que é uma busca que vai até o fim da vida com Pascal (essa idéia da prática como oposta à razão escolástica, a razão dos scholars). Mesmo nesse momento ele está se apresentando como um autor objetivista: a história encontra-se embutida no próprio conceito de habitus, ou o próprio conceito de capital, que toma de Marx e tenta generalizar no sentido de suas aplicações sociais mais amplas do que a economia estritamente, com a noção de capital cultural, capital social e etc. Enfim, há algo que eu gostaria de perguntar a Chartier, 
que acompanhou junto a Bourdieu essa passagem, nos anos 80, quando aparecem, logo depois de $O$ morto se apodera do vivo, esses artigos históricos, sobre a questão da região, da história da região, quando o próprio Chartier contribui com um artigo, publicado em Actes de la recherche sobre a divisão da França entre o norte e sul, quando aparecem progressivamente as análises das classes, do espaço social, da gênese das classes, quando Bourdieu se preocupa cada vez mais com esse lado da fenomenologia social, da subjetividade. Então, eu tenho uma pergunta a fazer sobre esse encontro de Bourdieu com uma área da história que estava se desenvolvendo, a história cultural, a microhistória, enfim, diversas correntes de diversos países que estavam se desenvolvendo nesse momento, ou o próprio diálogo com a história social inglesa, com Hobsbawm, com Thompson e outros. Havia um certo diálogo, além da publicação de artigos de historiadores em Actes de la recherche. ${ }^{10}$ Esse diálogo acabou reforçando um lado da obra de Bourdieu, e que vai se desenvolvendo ao longo do tempo, ao ponto de, justamente no seu período final, nos anos 90, em As Regras da arte, já se pode notar uma construção diferente das outras obras. Ele começa, quase à maneira de um historiador cultural, descrevendo qual é o contexto do romance de Flaubert, de $A$ Educação sentimental, a emergência do campo artístico naquele momento, para depois chegar, digamos assim, a considerações mais amplas, sobre a gênese dos campos e sobre considerações metodológicas. Depois também, em Meditaçôes Pascalianas, de 1997, a arma que ele utiliza contra a razão escolástica, em grande parte, são os fundamentos históricos da razão, é a constituição do campo da filosofia ou do campo da ciência. Então, o próprio conceito de campo, que inicialmente se colocava como uma aplicação do estruturalismo à sociedade francesa, a partir de um instrumental testado na lingüística, depois em sociedades menos diferenciadas, ele é depois pensado em relação a sociedades diferenciadas na França contemporânea para a área da educação e da cultura, para autonomizar essas áreas em relação ao econômico, o que seria uma forma de especificação histórica contida, sem muita explicitação, mas aparecia como um procedimento estrutural, e num certo sentido, de uma oposição à história. Mas, progressivamente, o próprio conceito de campo vai se atualizando como uma especificação histórica, e a importância da sua consti- 
tuiçãao histórica e de suas transformações adquirem um peso muito grande. Progressivamente a produção de Bourdieu ou a de seus colaboradores se caracteriza como uma história social da sociedade contemporânea, ou seja, o peso da história aumenta bastante. E talvez se possa ligar isso à sua múltipla formação, inclusive na filosofia, com os historiadores da ciência e os filósofos da ciência como Bachelard, Canguilhem e outros, que estão sempre preocupados com a historicidade dos conceitos, com a desconstrução e a construção histórica das categorias e dos conceitos. Bourdieu tem essa formação inicial e, ao longo do tempo, aproveita as classificaçōes de Durkheim e Mauss e as amplia (passando das classificações para a luta de classificações, generalizando a luta de classes de Marx). Então, eu perguntaria: qual é a visão que você tem dessa posição interdisciplinar ou entre fronteiras de disciplinas, desse encontro de Bourdieu com os historiadores - como, por exemplo, a discussão travada com Robert Darnton e com o próprio Roger Chartier ${ }^{11}$ —, rumo à transformação tanto da produção anterior deste autor, quanto da disciplina e do campo dos historiadores?

Roger Chartier: Parece-me uma idéia muito interessante e pertinente, a de uma profundidade histórica a cada etapa da trajetória intelectual de Bourdieu. E penso que você tem razão em mostrar que há um momento etnológico, sociológico, uma forma de sociologia cultural mais ampla. Há uma relação, em primeiro lugar, com a temporalidade: os estudos etnológicos são estudos do presente e quase com uma ausência da história. E, hoje em dia, se diz quanto aos estudos de Bourdieu sobre a Argélia, finalmente, que a guerra da Argélia é onipresente e quase ausente. Ou seja, que são estudos do tipo etnológico porque se dedicaram às comunidades não totalmente controladas e dominadas pelo exército francês. Mas é um pouco curioso — quando se lê agora e, particularmente, quando se lê em relação ao compromisso político tão forte de Bourdieu nos últimos cinco anos - ver que esses primeiros estudos se situam nesse momento e, finalmente, não consideram o evento histórico como um elemento essencial da compreensão. Esta vertente se erradica com $A$ Casa cabilia. E depois Bourdieu se volta para os estudos da França do século XX, os estudos sobre o sistema educacional, dos modelos educativos, pelo menos a partir da fundação da Escola Republicana. E ao mesmo tempo que Bourdieu publicava Os Herdeiros e $A$ 
Reprodução, comentava o texto de Durkheim sobre o sistema pedagógico francês. Assim, se podia ver uma inscrição dos mecanismos dos anos $60 \mathrm{e}$ 70 em algo que se remete à história do século XX. E podemos dizer que se abre para Bourdieu a história do século XX de diversas maneiras: com a dimensão da história da educação e com a leitura de alguns trabalhos de sociologia que se dedicavam não ao momento presente, mas ao imediato pós-guerra. Por exemplo, a tradução do livro de Richard Hoggart, La Culture du pauvre. Não devemos esquecer que Bourdieu tinha uma capacidade de trabalho excepcional. Ao mesmo tempo em que desenvolvia as pesquisas sociológicas estatísticas, escrevia artigos e livros, envolvia-se em projetos editoriais paralelamente à revista Actes de la recherche en sciences sociales, uma coleção essencial para a transformação da paisagem intelectual francesa, dos anos 60 até quase o presente. Dirigiu, ainda, a coleção Le Sens commun, publicada pelas Éditions de Minuit, na qual Bourdieu traduziu livros fundamentais que não pertenciam à referência francesa. Um deles foi este livro de Richard Hoggart sobre a cultura das classes operárias inglesas, imediatamente depois da II ${ }^{a}$ Guerra Mundial. E podemos pensar rapidamente que na história do século XX, tudo o que se remeteu à sociologia do esporte, à profissionalização, à transformação do campo, das práticas esportivas também contou com a sua contribuição. Isso foi muito importante, pois Bourdieu foi, na sua juventude, um jogador de rugby e gostava de esporte, gostava de rugby, e ao mesmo tempo pensou que este era um objeto sociológico legítimo, o que não era o caso na sociologia francesa depois da Guerra. Dedicar estudos ao esporte parecia completamente fora da legitimidade intelectual. Você disse - e me parece que tem razão - que o conceito de campo era cada vez mais elaborado quanto mais Bourdieu se acercava do século XIX, considerando que, para o campo intelectual, o campo estético, o campo literário, o século XIX é um momento chave. Os estudos que Bourdieu dedicou à Idade Moderna ou à Idade Média se vincularam, parece-me, a amizades intelectuais. Com Georges Duby teve uma discussão sobre as modalidades das formas de dominação simbólica na Idade Média e na sociedade contemporânea. Um dos amigos da École Normale Supérieure com o qual sempre manteve uma proximidade foi Louis Marin, o melhor especialista em Pascal na França, ou talvez no mundo. E Meditaçôes Pasca- 
lianas correspondem a leituras de Bourdieu e, ao mesmo tempo, são como uma homenagem e uma referência a Louis Marin. E ele encontrou em alguns dos historiadores que citei - que não necessariamente citavam Bourdieu - os pesquisadores mais fundamentais: em história da arte, Michael Baxandall; na história intelectual, Robert Darnton, que foi seu amigo e publicou em Actes de la recherche. Some-se ainda uma forma de reflexão de importância para o século XIX, dos marxistas ingleses, da interpretação aberta e inovadora do marxismo através de Thompson, de Hobsbawm ou de Christopher Hill. E, desta maneira, temos uma aprofundamento do sentido histórico de Bourdieu que vai finalmente deste modelo quase sem história — o de Lévi-Strauss — a um modelo da história contemporânea que dá sentido à descrição sincrônica que se alarga ao século XIX. Afinal de contas, para toda a perspectiva cultural, trata-se de um momento fundamental e que, finalmente, através do diálogo sobre as formas de dominação na Idade Média até o momento contemporâneo, seria uma maneira de entrar na obra não unicamente como uma mudança disciplinar (filosofia, etnologia, sociologia), mas também como uma presença de sentido histórico, da dimensão histórica na reflexão. E, finalmente, Bourdieu - pelo menos na França e por razões que são razões do campo intelectual francês - teve conflitos com historiadores do establishment. Ao mesmo tempo, se pode dizer que as colaborações que estabeleceu com os historiadores italianos, americanos, e outros foram quase à altura das relações que tinha com os sociólogos — para ele, a diferença de formação era importante, mas se diluía num projeto intelectual que, como dizia, não supõe que sociologia seja o saber do presente e a história um saber do passado, que não poderia e não deveria se fechar nos conceitos sociológicos para para propor análises. Parece-me uma leitura particularmente sutil da trajetória de Bourdieu em relação com a temporalidade e, a partir daí, com a história e com alguns historiadores.

ANDREa DAHER: Há também uma relação com a história que pode ser pensada, não apenas nesse sentido da trajetória de Bourdieu, da relação com a a diciplina e a interlocução com os historiadores, mas no sentido, por exemplo, da recepção dos historiadores franceses de um livro como La Distinction [A Distinção], publicado em 1979. Ela coincide com alguns marcos da tra- 
jetória da produção de Bourdieu, traçada por José Sérgio, que apontam para uma perspectiva mais histórica nas suas obras, a partir dos anos 80. Isso não se deu também, talvez, em função dessa recepção bastante particular por parte dos historiadores franceses de $A$ Distinção (e, ao mesmo tempo, da recepção da história social inglesa, que chegava também à França no final dos anos 70)?

Roger Chartier: Sim, a recepção de $A$ Distinção creio, resulta na primeira polêmica pública em torno de Bourdieu. Porque antes, só o livro sobre o sistema educativo havia tido uma grande ressonância pública, e muita gente tentou compreender maio de 68 a partir da publicação de Les Héritiers [Os Herdeiros], como se cada um dos estudantes envolvidos, comprometidos com o movimento estudantil, o tivesse lido. E, nesse caso, já havia um eco social, mas, se me lembro bem, não era o mesmo tipo de polêmica e de agressão, se pode dizer — em relação a Bourdieu. Porque, com A Distinção, todo um grupo do establshment intelectual, do qual, na França, participavam os historiadores, atacou Bourdieu por estar destruindo o "mistério estético", como uma forma de marxismo mecânica e vulgar, como uma forma de reducionismo sociológico. Por exemplo, ao publicar este livro, Bourdieu foi convidado a participar do programa de Bernard Pivot, que era um programa de televisão de consagração do livro pelo público. Foi, ao mesmo tempo, o livro que mais irritou alguns dos intelectuais franceses, porque talvez se pensava que, indiretamente, este livro destruía a aura - para falar como Walter Benjamim — da criação intelectual, da produção estética, remetendo-a a práticas de consumo que se vinculavam a condiçôes econômicas, posições sociais, vontade, distinção e etc. E lembro-me de uma polêmica muito dura na revista Le Débat e em outros jornais e revistas. Havia ataques a Bourdieu como dessacralizador e reducionista. Por outro lado, havia historiadores que claramente reforçaram sua leitura de Bourdieu através deste livro. E, por exemplo, me lembro de um programa de rádio que fiz nesse momento com Georges Duby sobre $A$ Distinção, em que ficou claro que, tanto este livro quanto Le Sens pratique [O Sentido prático], publicados no mesmo momento, são definíveis numa dupla perspectiva: uma mais teórica e a outra mais sociológica, uma mais estatística e a outra reflexiva. E A Distinção, antes da polêmica política de 1996, em 
que Bourdieu foi atacado de uma maneira muito violenta, era uma proposta de reflexão mais intelectual, cujas questões centrais também se remetiam à reflexão sobre o que é um intelectual ou como pensar a produção intelectual (sobretudo a última parte de $A$ Distinção, que é como uma crítica da crítica do juízo estético de Kant). A figura da autonomia do pensamento foi atacada com uma violência redutora contra a legitimidade filosófica, e nisso consistia a força de Bourdieu, que conhecia a filosofia tanto quanto os filósofos que o atacavam. Desta maneira, havia algo que lhe dá razão de recordar isto. É fundamental a referência filosófica; inclusive, ela aparece claramente não só nas Meditaçôes Pascalianas, mas está presente em todas as obras. Entretanto, $A$ Distinção teve reconhecimento público, foi uma denúncia violenta e uma inspiração para um modelo de compreensão dos mecanismos sociais e culturais, isto é, este mecanismo divulgação X distinção que muito historiadores utilizaram, mostrando que há sempre uma dinâmica de divulgação, apropriação, e daí a busca de uma nova distinção que cria uma nova vontade de apropriação.

José Murilo de Carvalho: O conceito de campo é, sem dúvida, muito rico, mas creio que ele inclui certa tensão entre história e sociologia. Porque, obviamente, ele se refere a uma realidade que é historicamente definida, qual seja, a diversificação e a multiplicação das esferas de atividade. Então, creio que não é à toa que Bourdieu tratou principalmente do século XIX, ou, mais exatamente, de um fenômeno da modernidade quando esses campos, essas áreas começaram a se definir. Nesse sentido, eu pergunto se a idéia de campo não é parte de uma sociologia da cultura mais ampla, mas cujo o uso se restringe especificamente à modernidade. Por exemplo, eu creio que, no caso brasileiro, o uso da idéia de campo para o nosso século XIX é problemático, porque uma das características principais desse século no Brasil é a indiferença entre esferas, entre o campo intelectual, o campo artístico e o campo político, por exemplo. Então, nesse sentido, creio que o conceito é rico, mas tem a limitação definida pela sua própria historicidade. Não sei se concorda com esta observação.

Roger CHARTIER: Sim. Tentei respeitar este ponto, porque quando abri esta discussão sobre o que é o espaço da criação literária antes do momento que Bourdieu descreve como o da cristalização de um campo literário - com 
polaridades bem estabelecidas, primeiro, pela arte, depois a literatura industrial, e entre um e outro momento todo um leque de posturas - não utilizei o conceito de campo e me perguntava sobre como descrever este espaço. Um espaço que está dentro da esfera do exercício de poder, um espaço que tem suas primeiras formas de autonomização, um espaço que talvez suponha uma dispersão, uma disseminação do que é uma produção literária dentro de uma pluralidade de instituições (a igreja, a corte). Desta maneira, esta é uma questão aberta, e o que me parece muito importante na sua observação é evitar fazer com Bourdieu o que Bourdieu queria evitar fazer com as categorias universais da criação. Há uma historicidade na obra de Bourdieu inscrita no momento em que a diferença destes diversos espaços é muito forte. Há também um segundo caráter de historicidade, que é a validade da descrição. Podemos também discutir isto: a validade da descrição para este momento, no século XIX, quando se organizaram estes espaços, agora melhor definidos como campos, mas deixar em aberto a maneira de descrever os espaços sociais de produção estética, e a partir daí, se pensarmos na cultura, definirmos como se organiza a relação entre ela a corporação, a corte ou o ateliê para o mercado. Ou se considerarmos a literatura, podemos pensar como se organiza a relação entre ela, as instituiçóes monárquicas, a república das letras ou o mercado editorial. Ou ainda, se podemos pensar na produção científica, como por exemplo no tempo de Galileu, quando se organiza a relação entre a universidade, a corte e uma nova forma de república dos sábios. Creio que trabalhar com Bourdieu aplicando mecanicamente a categoria de campo seria introduzir a idéia de uma categoria universal sem dar suficiente atenção às descontinuidades. E há em Bourdieu também, uma proposta de descontinuidade. Não se trata de um pensamento da necessidade, nem da conseqüência, nem da continuidade. Porém, vimos lamentavelmente na França aplicações muito mecânicas dos conceitos de Bourdieu, de seu valor heurístico, quando aplicados sem a descriminarão em relação à especificidade de cada configuração social. Para um artista do século XVI, pertencer a uma corporação ou sair para uma corte, não tem nenhum sentido no século XIX, não há mais corporações de grêmios. Vê-se que aqui há algo absolutamente específico. E há um ensaio de Bourdieu que trata do tema da moda, do artista que quer 
sair da corte. Este pode contemplar a possibilidade de viver de sua arte, vendendo as partituras ou cobrando para concertos e, inclusive, fracassar nesta possibilidade, porque no século XVIII não existem as condições de um campo musical no qual as possibilidades de mercado para a música escrita ou tocada sejam suficientes. E é um problema saber se se pode falar num campo musical no século XVIII; penso que não. Entretanto, há instituições ou lugares no espaço social nos quais se produz, se compóe e se toca a música. E é uma das mais fortes apostas de Bourdieu: lançar este desafio para pensar o conceito chave de campo, a descontinuidade dos espaços de criação intelectual e artística. Os outros conceitos como dominação simbólica ou prática, ou talvez habitus, não me parecem da mesma natureza, porque podem levar em consideração a descontinuidade de sua constituição, de sua definição. A dominação simbólica se define como uma dominação que não supõe o recurso imediato à força, e ela se define como a incorporação dos princípios da dominação, inclusive pelos dominados. Pode ser utilizado com a descontinuidade histórica dos mecanismos que instalam tal dominação na Idade Média, no século XVI, ou no século XX, e particularmente se liga com a idéia de um processo de civilização que reduz o uso direto da força e aumenta, como pensava Bourdieu, a importância das lutas simbólicas como lutas sociais. Desta maneira, vemos que há outros conceitos fundamentais para Bourdieu que podem suportar a descontinuidade histórica. Quanto ao conceito de campo, não me parece ser assim. Penso que nisto tem razão.

José Murilo de Carvalho: O conceito de dominação simbólica é sem dúvida de um alcance muito maior do que o de campo e permite um uso mais despregado da temporalidade. A pergunta que tenho em relação a ele é em que medida destoa do conceito marxista de ideologia, mais precisamente, do conceito gramsciano de hegemonia, o exercício da dominação por via simbólica, sem recurso à força.

Roger Chartier: É possível situar a obra de Bourdieu em filiação com a de Marx, numa relação com os marxistas ingleses, como recordamos. Porém, como uma possibilidade para desqualificar sua obra, diziam que ele era o último marxista francês. Parece-me que Bourdieu não manejou muito freqüentemente os conceitos marxistas, nem sequer há referências cor- 
rentes a Marx, que conhecia muito bem, para além da estatística das referências ou das citações. E não sei se, no caso, havia um outro elemento específico do espaço intelectual francês. É que, a partir do momento destacado por José Sérgio, da passagem de Bourdieu da etnologia a uma forma de compreensão sociológica, havia na França o pensamento - senão dominante, muito importante - de Althusser. E uma parte da obra de Bourdieu foi escrita contra Althusser, contra os aparelhos ideológicos do Estado.

Quanto ao conceito de ideologia, lembremos o diálogo de Bourdieu com Georges Duby, em torno de seu livro Les trois ordres ou l'imaginaire du féodalisme [As três ordens ou o imaginário de feudalismo]. Nele, Duby lançava mão da categoria de ideologia, o que para Bourdieu devia ser pensado a partir da categoria de sistemas de representações coletivas, à maneira de Durkheim, ou de formas de imposição de classificações. Essas noções correspondiam mais ou menos ao sentido que Duby dava a ideologia, ou melhor, à pluralidade das ideologias de percepção e construção do mundo social, em seu trabalho sobre as três ordens. Seria necessário, para responder completamente a sua pergunta, aprofundar a análise para ver onde existem diferenças teóricas entre essas categorias, mas não pensar que, pelo fato dos termos serem diferentes, haja necessariamente muita diferença nas concepções. Desta maneira, seria uma análise da relação entre a maneira de expressar e o conteúdo teórico do enunciado.

ANDREa DAHER: Mas ao lançar mão de conceitos como o conceito de habitus - que Bourdieu diz escolher diretamente de Panofsky por ser o sentido mais aristotélico, propriamente, do conceito - é uma renúncia, ou pelo menos uma denúncia da insuficiência de outros conceitos mais coletivizantes como ideologia, mentalidades, como outros conceitos em voga exatamente nesse momento. Quer dizer, ao mesmo tempo há um distanciamento de um determinado conceito de ideologia.

Roger CHARTIER: Sim, porque Bourdieu queria pensar nesta dimensão da incorporação, e os outros conceitos podiam parecer intelectualizados demais. Tenho aqui uma definição de habitus — há muitas, na obra de Bourdieu - que aponta para um sistema de esquemas de percepção, de juízo, de apreciação e de ação inscritos no corpo pelas experiências passa- 
das e permitindo atos de conhecimento prático. Quer dizer que, no sentido desta definição, há uma vontade de distanciar-se de algo muito conceitualizado. O habitus é algo que está no corpo. E habitus neste sentido é uma incorporação, uma incorporação de esquemas, e como disse, que permitem o conhecimento prático, o ajuste à situação, algo não reflexivo. E a distância aparece entre todo um vocabulário que conduzia a uma idéia de reflexividade ou de intelectualização nas pesquisas sobre as experiências passadas e o que expressava o mundo social dentro do corpo e transformando em esquema imediato, em esquema automático de percepção - e daí um vocabulário que devia mudar o vocabulário da história das mentalidades, muito inerte. Citando Leibniz, Bourdieu indica que "somos afinal empíricos em três quartos de nossas ações". Esta é a razão pela qual o conceito de habitus tinha esta importância, tal como se construiu. Você sabe qual foi a primeira aparição do conceito de habitus? Não sei se aparece nos trabalhos de etnologia, não tenho certeza, não verifiquei.

José Sérgio LeITe Lopes: Uma das primeiras aparições é para pensar os conceitos de ethos, de disposição cultural, que estão presentes nos textos sobre a Cabília dos anos 60, e que são repensados no livro Esquisse d'une théorie de la pratique, de 1972. Aí aparece o conceito de habitus em toda sua pujança e em toda a sua centralidade na obra de Bourdieu, e depois retomado em Le Sens Pratique, de 1980. Mas este conceito também aparece anteriormente em Un art moyen, essai sur les usages sociaux de la photographie, que é de 1965, e ainda no posfácio ao livro Architecture gothique et pensée scholastique, livro traduzido e editado por Bourdieu em 1967'2, numa intenção de elaboração do conceito de habitus presente em estado prático, por assim dizer, nesta obra de Panofsky. Bourdieu estaria, em meados dos anos 60, num período de experimentação da transposição de noções elaboradas em sua experiência etnográfica na Argélia (e também com o campesinato de sua região natal) para situaçóes nos universos da educação e da cultura da sociedade diferenciada francesa, antes de voltar ao seu material etnográfico argelino para uma exposição sistemática da noção de habitus no Esquisse, em 1972.

Roger CHARTiER: E como dizia Andrea, e recordando outro título da coleção Sens commun, houve a tradução de Arquitetura Gótica e Escolástica, de 
Panofsky, livro em que se encontra o conceito de habitus e de habits forming forces. Nele, vemos que os arquitetos do século XIII e os filósofos escolásticos constróem, os segundos suas demonstrações e os primeiros seus edifícios, de acordo com a mesma organização intelectual. Panofsky remetia esta mesma homologia - o que designava como habit forming forces - a dois tipos de produção sem relação: uma glosa escolástica e uma catedral gótica. Mas a leitura de Panofsky fornece uma formulação rudimentar do conceito de habitus. Penso que ele havia chamado a atenção de Bourdieu e depois, paralelamente, a leitura de Elias, que também utiliza a mesma noção. Bourdieu conduziu a uma elaboração teórica muito mais complexa da categoria, que se tornou central a partir, talvez, de $A$ Distinção, de O Sentido prático.

José Sérgio Leite Lopes: Ao contrário de campo, que é justamente um conceito, uma categoria para explicar a sociedade moderna, a diferenciação, a sociedade diferenciada, o conceito de habitus, Bourdieu vai buscá-lo em Panofsky, na sociedade medieval e também nos estudos etnológicos da Cabília. Ele vai ser identificado na disputa da honra, na lógica da honra, nas estratégias matrimoniais, e outras, que apontam para essa possibilidade de ação, e Bourdieu vai formular a teoria da prática por esta via. Mas o conceito de habitus terá uma aplicabilidade mais ampla do que o contexto social em que foi inicialmente pensado (a sociedade camponesa da Cabília ou do Béarn francês, ou ainda a sociedade medieval estudada por Panofsky) e será estendido para a explicação da prática também nas sociedades diferenciadas e modernas.

Luiz Cristiano Oliveira: A minha pergunta é sobre a produção simbólica antes do século XIX, antes da constituição dos campos, ou seja, antes da constituição de uma esfera autônoma de produção. E eu gostaria de retomar um pouco a palestra de ontem, onde o senhor mencionou que nos séculos XVI e XVII os escritores utilizavam largamente lugares-comuns em suas obras. E a respeito disso, queria perguntar como ficaria a escrita da história nos séculos XVI e XVII? Haveria uma tensão entre a escrita desses lugares-comuns e a investigação mais original, a investigação dos fatos?

Roger Chartier: Há dois segmentos para esta resposta, e há um que poderia vincular-se com o tema de hoje. Por que se escreve a história nos sé- 
culos XVI e XVII fora de um campo acadêmico, não se ensina a história nas universidades, nem sequer podemos dizer nos colégios? Desta maneira, por que se escreve a história e onde, em que espaço social se escreve? Claramente, se pode escrever na dependência de uma visão religiosa, e particularmente mobilizando a história nos conflitos entre protestantes e católicos. Pode-se escrever dentro do meio aristocrático, a serviço de reivindicações, privilégio de famílias nobres. Pode-se escrever para justificar a antigüidade de uma cidade contra as outras. Há todo um leque, um espaço plural de instituições ou lugares nos quais se escreve a história. Em seguida, seria necessário vincular o tipo de história que se escreve com o lugar em que se escreve, porque pode-se ter uma dependência estrita do tipo de história com o lugar e o pedido da ordem religiosa da cidade, do rei. Há aqui toda uma reflexão contida em livros já publicados. Para o caso da França, há o livro de Georges Huppert, L'idée d'histoire parfaite [A idéia de história perfeita] sobre o surgimento, no final do século XVI, de uma forma de história que se definia como uma história crítica que utilizava os documentos, mas ao serviço de uma história universal, de uma história perfeita. Desta maneira, há toda uma discussão em torno de lugares de escrita e, a partir daí, sobre a condição de historiador quando ainda não existe a profissão de historiador. Deve-se considerar ainda o que você mencionava dentro da demonstração histórica, a tensão entre o uso do método clássico dos lugares-comuns, isto é, a recopilação de livros já presentes e particularmente dos fragmentos, extratos, encontrados nestes livros e a aparição, como dizia ontem em torno de Lorenzo Valla. ${ }^{13}$ Mas isso também se dá com esta história dos antiquários, dos que buscavam testemunhos textuais arqueológicos, no final do século XVI, e que poderia se inscrever dentro do modelo global dos lugares-comuns e ser acrescentado a todas as provas do que foi lido, escutado e visto, sem que uma diferença de autoridade epistemológica seja introduzida na comparação das diversas fontes; ou ainda poderia estar a serviço de uma história crítica que fundamenta uma crítica filológica dos documentos e uma crítica histórica dos rastros históricos. Desta maneira, é uma relação de três elementos: o lugar de produção da história, a modalidade da história escrita e a técnica intelectual entre lugares-comuns e a aproximação crítica. É a articulação entre estes elementos que poderia 
definir uma aproximação da história nos séculos XVI e XVII; seria aplicar a este momento histórico o questionário que segue Michel de Certeau em seu ensaio, A operação historiográfica. ${ }^{14}$ De Certeau começa a refletir com a instituição, segue na direção dos gêneros que implica a instituição, e finalmente analisa a dupla dimensão retórica, narrativa e epistemológica do discurso. Aplicar este questionário me parece uma boa maneira de evitar o reducionismo e o idealismo. Mas se se remete o discurso às suas condições de produção e de possibilidade, há reducionismo quando se pensa que a história é unicamente a justificativa de privilégios, direitos, demandas, ideologias, etc. É certo haver sempre tensão entre o lugar da produção e o conteúdo histórico produzido, e seguir este caminho conduziria à possibilidade de situar cada tipo de história em relação a outros tipos na mesma sociedade. É um pensamento relacional, inspirado por Bourdieu.

Giselle Venancio: Algumas idéias desenvolvidas por Bourdieu nos servem muito bem para um trabalho sobre biografias, por exemplo. O conceito de habitus, a questão das determinações externas, a formação do campo e um itinerário pessoal ou individual dentro desse campo. Eu gostaria de saber se se pode fazer uma relação entre a produção de Bourdieu, a partir dos anos 80, onde ele desenvolve essas categorias mais históricas, como o professor chamou a atenção, e uma certa redescoberta da biografia pelos historiadores, uma certa produção ligada à biografia pelos historiadores.

Roger Chartier: Em primeiro lugar, não devemos equivocar-nos com o que significa o redescobrimento por parte dos historiadores da biografia, porque como gênero clássico a biografia nunca desapareceu. Se lermos o catálogo de uma editora como a Fayard, a partir do começo de XIX, e inclusive depois da Segunda Guerra Mundial, as biografias são o gênero dominante. Mas o que você menciona é outra coisa, é o redescobrimento da biografia dentro de tradições históricas que a haviam recusado por ser puramente ligada ao evento, ao indivíduo isolado, a um gênero de narração superficial. Recentemente, como o ápice deste movimento, o livro de Le Goff sobre Saint Louis teve um êxito incrível, num momento de diminuição das vendas dos livros de história. Podemos dizer que uma prática microhistórica se vincula com a biografia, livro de Giovanni Levi, $A$ herança imaterial, ou ainda Carlo Ginzburg, que escreveu uma verdadeira bio- 
grafia de Menochio, e até mesmo de Piero Della Francesca. Nisso residia o problema para os historiadores: a idéia de que seguir uma biografia não era necessariamente entrar na pequena história e reproduzir os modelos canônicos da vida desde o nascimento até a morte. Então, como isto pode ligarse com Bourdieu? O importante é a maneira como Bourdieu pensa as trajetórias de vida, porque não escreveu, como os historiadores, biografias, exceto a sua própria, talvez, nos últimos momentos. Pensar a articulação entre trajetória de vida e o conceito de campo ou de espaço social antes dos campos, é fundamental. É a idéia de que é o indivíduo que pode produzir uma mudança, é o indivíduo que muda segundo a sua trajetória social, a sua condição, o seu estado, a sua profissão, as suas produções durante toda a sua vida. José Sérgio esboçava isso para Bourdieu, com etapas dentro de um mundo intelectual ou de um campo de produção mais ou menos estável. Há ainda o indivíduo que não modifica nada de sua condição, de sua postura e de sua produção intelectual, num momento em que o campo muda. Bourdieu sempre utilizava o exemplo de Dom Quixote, isto é, alguém que está em desacordo com seu tempo, que está contra o campo, pois o mundo literário havia mudado. E Dom Quixote se encontra com os valores de um mundo social ou de um gênero literário, a novela cavalaresca, num momento em que não se imprime ou não se crê mais neste tipo de novela, e no qual, evidentemente, a Espanha mudou, e os valores aristocráticos da Espanha feudal desapareceram frente à construção do Estado moderno. Há um artigo magnífico de Pierre Vilar, historiador marxista francês, sobre o tempo de Quixote que evoca exatamente isto. Desta maneira, seria a lição principal de Bourdieu: não se pode pensar a vida de um indivíduo sem situá-la, de forma relacional, dentro do espaço global ou específico no qual se encontra. E ver que ele pode mudar, porque ele mesmo muda ou porque muda o espaço. Não tenho certeza de que haja uma relação direta entre este modelo teórico e os usos históricos da biografia, mas um ponto comum seria que a trajetória individual está vinculada a um mundo social inteiro. Se Ginzburg escreve uma biografia (entre aspas) sobre Menochio é porque lhe interessa a cultura camponesa - agrária, primordialmente — da qual Menochio representa uma expressão ao mesmo tempo exemplar e singular. Daí este conceito paradoxal de um historiador 
que faleceu há alguns anos, Edoardo Grendi, de "excepcional normal”; a categoria do excepcional como normal. Ou ainda, se Jacques Le Goff se interessou por Saint Louis, que não deixou nenhum testemunho pessoal particular, é porque através de São Luís existia a possibilidade de ver e de se vincular à questão da história, à construção da história a partir de uma escrita plural dos historiadores, dos legistas, das lendas e muito mais. De toda maneira, o comum entre essas duas dimensões é o seguinte: trajetórias individuais em Bourdieu e biografia a serviço de uma compreensão de mecanismos compartilhados nessa nova forma de história; é a idéia de que o indivíduo está em relação com os outros. Desta maneira, a biografia sempre implica a coletividade.

ElizABETH LEAL: Bourdieu propõe uma teoria da prática e da ação. Isso relacionado à produção da arte me parece se reduzir às negociações para produzi-la, em determinadas utilizações da proposta de Bourdieu. Não há aí um perigo, por exemplo, de perdermos o objeto final do nosso estudo, que é a própria obra? E a minha pergunta é absolutamente egoísta: com isso, é possível eu associar por exemplo a análise iconográfica de Panofsky com a teoria da prática de Bourdieu, sempre tendo a atenção de não cair novamente numa idéia essencialista ou numa idéia de valor estético em si da obra? Eu acho que Bourdieu nos ensina um pouco nesse sentido de que a obra não tem apenas um valor estético, e na análise mais tradicional dentro da história da arte, tem valores simbólicos outros, mas não apenas um valor estético. Então, é possível aliar a análise iconográfica de Panofsky tentando buscar também outros valores, e dentro deles o estético, e a teoria da ação e da prática de Bourdieu? Ou isso é um Frankenstein?

Roger Chartier: O problema continua. Não me parece que haja um desaparecimento da obra. Em primeiro lugar, porque a perspectiva de Bourdieu finalmente é, por um lado, uma sociologia das apropriaçóes e dos usos das obras culturais, por exemplo em A Distinção. Mas, por outro lado, não me parece que é uma história, uma sociologia, como se pode dizer, pós-moderna da dissolução, do desaparecimento do ato criador, de uma proposta de criação. E o que Bourdieu propõe, em relação a Manet, num livro que deverá ser publicado, suponho, e em relação a Flaubert, se pode discutir, mas, de todo modo, não há dissolução da obra. O que me parece é que 
para Bourdieu o valor estético incluía em si mesmo esta reflexão imediata, prática, espontânea da obra sobre a própria sociedade e, talvez, suas próprias condições de produção. Ou seja, não era uma definição estética puramente formal, se se pode dizer assim, mas propóe que o valor puramente estético não pode destacar-se da posição que a obra ocupa em relação com as outras obras de seu tempo ou com o espaço social particular ou global na qual se situa. E daí, talvez, surja uma tensão que deve ser pensada, pois não quero dizer que Bourdieu disse tudo sobre este ponto. Mas uma idéia importante, em primeiro lugar, é a de que as normas estéticas num momento dado se distribuem segundo posiçōes, trajetórias e interesses. E o segundo elemento importante, é que o que poderia definir a força específica de certas formas, é esta dupla dimensão: a sua capacidade a ser passível de uma pluralidade de reapropriações através dos tempos, dos lugares, das línguas, e também a relação aguda que tem com seu próprio tempo. Pensemos em Dom Quixote, que, como dizia, é um livro que tem suas raízes nas mudanças políticas, sociais e estéticas da Espanha do Século de Ouro. E, ao mesmo tempo, é talvez a obra mais aberta, lado a lado com a de Shakespeare, às reapropriações através dos tempos, dos lugares e das línguas inclusive fora das línguas, dos figurinos, das festas, até mesmo imediatamente após as publicaçôes. De toda maneira se vê que aqui há toda um modo de pensar a densidade estética das obras neste entrecruzamento entre a situação dentro de seu tempo e a capacidade de reapropriação, o que permite pensar que não há uma igualdade generalizada entre elas. Lembrome sempre de uma citação de Borges que dizia: "Não é porque o mistério estético não é decifrável que não devemos considerar todos os fatos que o fizeram possível”. Pelo menos para os sociólogos ou historiadores, uma primeira pesquisa deve se dedicar a esses fatos que o fizeram possível e que recordamos durante este seminário. Mas se quisermos ir dos fatos ao mistério, é claro que uma das chaves do mistério é o que chamo - e aqui não estou comentando Bourdieu — a densidade estética, que permite — quando não é suficiente, não o permite - esta dupla relação da obra com seu presente e da obra com o seu futuro, num certo sentido. E o exemplo de Rembrandt podia ser o melhor nesse sentido, porque foi um pintor que afirmou a irredutibilidade do valor pictórico, que não dependia mais do preço 
das matérias, não depende mais da capacidade a uma representação adequada. Rembrandt em seu ateliê produz uma mercadoria, algo que deve vender e que para ele é quase uma moeda. E no caso de Rubens também, o valor pictórico é irredutível e deve referir-se ao artista. Ao mesmo tempo, o ateliê se abre a uma produção de quadros que suporta ser compatível com as cópias ou com o trabalho coletivo dos alunos para as partes menos difíceis do quadro. E daí, no tempo contemporâneo, todo o problema da atribuição dos Rembrant a Rembrant. Há alguns museus da Europa, como o Museu de Dresden, que foram obrigados a considerar talvez uns dos mais famosos quadros de Rembrant como resultado de trabalho coletivo ou de cópias. É uma série de paradoxos: a singularidade da pintura do artista, a idéia de que o valor econômico depende diretamente deste valor estético e, finalmente, o lugar do pintor afirmado como tal porque é este lugar que dá valor econômico aos quadros. Bourdieu que não tratou diretamente de Rembrant, mas, implicitamente, lhe parecia que Manet ou Flaubert tinham a capacidade de reflexão no ato estético sobre sua sociedade e sobre sua prática e, ao mesmo tempo, produziram obras cuja densidade permite a resistência, inclusive à análise do sociólogo.

RAImunda Gomes: Eu gostaria de entender um pouco mais a noção de dominação masculina em Bourdieu, porque tenho a impressão de que ele está falando só das práticas de dominação. $\mathrm{O}$ outro não existe, os dominados não existem para ele ou ele está falando só da prática da dominação em si? Eu vejo como se o outro não fosse sujeito, ele apenas absorve as práticas. Roger Chartier: Este livro La domination masculine [A dominação masculina] se dedica, como muitos trabalhos de história das mulheres ou da história da construção dos sexos, à idéia de que se uma forma de desigualdade ou dominação se reproduz é porque há discursos ou representações que a naturalizam, e que, naturalizando-a, é imposta a cada um, homens e mulheres, pode-se dizer. Isto não significa que não haja sujeito, que não haja distância e que não haja possibilidades — seja através de um modelo de ruptura, seja, como muitas das minhas colegas historiadoras na França mostraram, dentro do consentimento - de recusar, criticar, deslocar estes princípios nas formulações mais fortes - como a do movimento de liberação das mulheres ou, de uma maneira mais coletiva, mais anônima, mais 
espontânea de crítica ou como a recusa das modalidades mais imediatas desta dominação masculina. Desta maneira, o livro tenta mostrar estes dois elementos, mas se poderia dizer que muitas das feministas, por exemplo, fizeram pesquisas nesta mesma dimensão. Lembro-me de um livro de Joan Scott em que o importante é compreender, finalmente, como os discursos reforçam esta dominação e produzem uma repetição das representaçôes de uma desigualdade jurídica, política, cívica, social, de espaços separados, domésticos, públicos, etc. Todos estes discursos reproduzem a forma de dominação. Se no século XX é questionada a forma de dominação masculina e se buscam precursores e precursoras de uma outra representação do mundo social — mas sempre marginal e minoritária nas sociedades antigas - isto é claramente a indicação de que durante muito tempo se reproduziu esta dominação. O que mostra Joan Scott nesse livro, que se chama em inglês Only paradoxes to offer, que foi traduzido para o francês, é que a partir do século XIX, em um nível mais consciente, mais formalizado, há mulheres que mobilizam discursos, não especialmente feministas no seu gênero, para introduzir dentro destes discursos, por exemplo, a filantropia, ou a cidadania, ou o discurso da reivindicação social, introduzir uma dimensão de questionamento da reprodução ao mesmo tempo objetiva e discursiva da dominação masculina. E se poderia ler esse livro de Joan Scott ao mesmo tempo que o livro de Bourdieu. Mas como dizia, a impressão deixada se vincula com essa perspectiva que faz de Bourdieu um obcecado pela reprodução das dominações quaisquer que sejam. Finalmente, não são descritas da mesma maneira as condições de possibilidade da destruição ou do questionamento desta dominação. E se vê, ao final do seu livro, uma ruptura um pouco rápida entre a descrição na sociedade de Cabília ou, na sociedade francesa, deste modelo da dominação para pensar que existe outros tipos de relações. Mas falta algo, há como hiatos entre as descrições da dominação e as últimas páginas muito poéticas sobre a igualdade, o amor e o encontro. Parece-me que se pode encontrar no livro de Joan Scott a idéia de que o discurso, por um lado, reforça a dominação, mas que há uma possibilidade de mobilização deste discurso diferente do discurso que reforça constantemente a natureza de uma dominação de fato, socialmente construída. Em geral poder construir um repertório do feminismo me parece 
bom, mas neste trabalho de construção sempre se encontra com movimentos ou figuras muito marginais, dos séculos XVI ao XVIII. No entanto, a partir do século XIX, através da reivindicação social, através de um papel público e através de uma reivindicação política, finalmente há uma emergência, uma presença de um outro modelo, e talvez agora estejamos num momento em que se abre um novo capítulo nesta história. Aqui se pode ler, se pensarmos nos franceses, os livros de Michelle Perrot. Há também o livro de Thomas Laqueur sobre a representação anatômica e fisiológica dos sexos. O título em inglês também é um jogo de palavras: Making Sex [em português, Inventando o sexo]. Durante muito tempo, até o século XIX, a representação médica e anatômica dos dois sexos considerava que eram idênticos, apenas num caso os órgãos sexuais eram exteriores e, no outro caso, eram interiores. Mas havia um modelo único de representação anatômica dos dois sexos, que dava esta identidade à representação anatômica, mas que implicava que a justificativa da desigualdade se vinculava com esta pequena diferença, isto é, com a construção cultural. A partir do século XIX, o que se vê é a busca de uma medicina para identificar as diferenças quase psicológicas ou anatômicas ou fisiológicas entre os indivíduos, acentuar a diferença das características femininas para demonstrar sua inferioridade, sua debilidade em termos de força, inferioridade, em termos de nervosismo. E trata-se de um discurso que se constrói a partir de um discurso fisiológico que tenta mostrar uma radical diferença entre os sexos, onde todos os elementos femininos aparecem num sentido de inferioridade e todos os outros num sentido de superioridade. O livro de Laqueur é interessante porque mostra que se pode justificar uma dominação masculina a partir de dois modelos muito diferentes de representação. Há muitas imagens de representação anatômica e fisiológica dos dois sexos, o que demonstra que era necessário a construção social desta diferença, que pode utilizar modelos objetivos (entre aspas) de representação física completamente opostos, mas a serviço da mesma reiteração de uma desigualdade social.

Alexandre Nascimento: Como o senhor vê a relação entre Bourdieu e Abdelmalek Sayad? E como isso influenciou a obra de cada um? Eu acho isso extremamente interessante, porque me parece que eles têm um ponto de chegada comum e origens diferentes. 
José Sérgio Leite Lopes: Abdelmalek Sayad trabalhou com Bourdieu na Argélia nas pesquisas sobre o campesinato, sobre os trabalhadores e subproletários argelinos. Foi aluno de Bourdieu, que dava aula na faculdade de letras e ciências humanas da Argélia. Depois, Sayad foi para a França e se integrou na equipe de Bourdieu, no Centro de Sociologia Européia, Centro de Sociologia da Educação e da Cultura. A diferença entre os dois é interessante, embora os dois sejam complementares. Publicaram um livro juntos, Le Déracinement [O Desenraizamento] e produziram alguns artigos conjuntos, fruto de suas pesquisas sobre a Argélia. A Sayad Bourdieu dedica o livro Esquisse d'une théorie de la pratique. Há, então, uma proximidade muito grande entre eles. Abdelmalek Sayad foi o introdutor de Bourdieu no trabalho de campo na área da Cabília, na sua própria área de origem. Depois, Sayad começou a trabalhar com os argelinos imigrados na França e, ao contrário de Bourdieu, que trabalhou mais com os campos a partir da dominação, do centro da dominação, Sayad estudou os dominados, os periféricos, principalmente os trabalhadores imigrados na França, durante toda a sua vida. Trabalhou muito com biografias, com material de entrevistas de trabalhadores em diferentes situações, e isso estimulado por Bourdieu - embora Bourdieu não viesse fazendo esse tipo de trabalho diretamente desde seus trabalhos na Argélia (a não ser em alguns materiais ilustrativos de $A$ Distinção). E pode-se constatar que nos anos 90, com La Misère du monde [A Miséria do mundo], o tipo de trabalho que Sayad sempre desenvolveu foi usado um pouco como um modelo para diferentes situações na França, não somente no que diz respeito a trabalhadores imigrados, mas outros tipos de trabalhadores franceses. Entrevistas aprofundadas foram feitas e generalizadas a partir desse momento. Bourdieu dizia que Sayad era um escritor público, um écrivain publique, porque ele dava voz, ou ampliava, ou sistematizava os discursos desses trabalhadores ou dessas situações de dominação, dessas experiências que são invisíveis ou que são esmagadas, marginalizadas na sociedade francesa. Então, a trajetória de Sayad é complementar à de Bourdieu. Quando ele morreu, Bourdieu ainda trabalhou em cima de um livro de Sayad que estava incompleto, inacabado. ${ }^{15}$ Enfim, havia uma relação de amizade e de complementaridade bastante grande entre os dois, pois Sayad era o especialista de grupos do- 
minados da sociedade francesa e, ao mesmo tempo, tinha o conhecimento histórico da gênese desses trabalhadores, desde sua situação de origem até a França, e dessa ambigüidade, desse retorno, dessas idas e vindas, desse "sentir-se estrangeiro" na área de origem e na área de chegada. Então, digamos que Sayad é estratégico na compreensão dos problemas sociais da França atual, que passam por essa relação com os trabalhadores imigrados que se tornaram franceses de segunda e terceira geração - e que, por sua vez, são estratégicos, como comprova hoje a política francesa de extrema direita de Le Pen e de outros, em que é central a expulsão dos imigrantes, dos estrangeiros. Sayad viveu isso na carne, transmitiu essa experiência, e na sua pesquisa - aliás também como Bourdieu — está a sua própria trajetória também, embora ela não seja explicitada. Através da pesquisa dos outros, ele faz uma análise da sua própria trajetória. Mas, de fato, existe entre os dois, Bourdieu e Sayad, uma diferença de ênfase: na produção de Bourdieu há a predominância da análise sobre os mecanismos de reprodução da dominação e não há uma atenção correspondente às contradições e aos movimentos que podem surgir dali. (Um pouco talvez como o próprio Marx embora Marx tenha textos históricos como $O 18$ de Brumário, por exemplo, que não têm a mesma estatura de $O$ Capital. Enfim, Marx morreu antes de fazer o capítulo sobre as classes, sobre as lutas de classe). Podemos dizer que Bourdieu morreu deixando escritos políticos onde procurava dar sugestões de mobilização, como Contre-feux e Contre-feux 2 [Contrafogos $1 e$ 2]. Ele procurava uma base analítica que talvez encontrasse em outros estudiosos que trabalharam com ele ou com quem pôde ter relaçôes e que procurava estimular. Aliás, recentemente foi publicada uma coletânea das intervenções políticas de Bourdieu ao longo de sua carreira, ${ }^{16}$ desde seu período de pesquisa na Argélia, que dá nova perspectiva ao seu posicionamento, mais visivelmente público a partir de 1995.

\section{Notas}

${ }^{1}$ Publicado na revista Theory, Culture and Society, vol. 4, n ${ }^{\text {os } 2-3, ~ j u n h o ~ d e ~} 1987$.

${ }^{2}$ O nascimento do leitor moderno no Século de Ouro. Definiçôes, representações e práticas a cultura escrita. Conferência proferida no dia 29 de abril de 2002, no Real Gabinete Português de Leitura, a convite do Programa de Pós-graduação em História Social.

Topoi, Rio de Janeiro, set. 2001, pp. 181-185. 
${ }^{3}$ Le mort saisi le vif. As relações entre a história reificada e a história incorporada. In: $O$ poder simbólico. Lisboa, DIFEL, 1989, pp. 75 a 106.

${ }^{4}$ Idem, pp. 133 a 161.

5 Travail et Travailleurs en Algérie. Paris-La Haye: Mouton, 1963 (com A. Darbel, J.-P. Rivet e C. Seibel).

${ }^{6}$ La Maison kabyle ou le monde renversé. In: J. POILLON et P. MARANDA (org.). Échanges et communications. Mélanges offertes à Claude Lévi-Strauss à l'occasion de son 60e. anniversaire. Paris-La Haye: Mouton, 1970, pp. 739-758. Texto incluído nos livros de P. Bourdieu, Esquisse d'une théorie de la pratique (Genève: Droz, 1972) e Le Sens Pratique (Paris: Minuit, 1980). Há tradução brasileira em Cadernos de Campo. São Paulo, 8(9), pp. $147-159$.

${ }^{7}$ In: Science de la science et réflexivité. Paris: Raisons d'Agir, 2001, pp. 184-220.

${ }^{8}$ Célibat et condition paysanne. In: Études Rurales. Paris, n ${ }^{\circ} 5-6$, avril-septembre 1962 , pp. 32-136.

${ }^{9}$ Roger CHARTIER. Science sociale et découpage régional: note sur deux débats (18201920). In: Actes de la Recherche en Sciences Sociales, n 35, nov. 1980, pp. 27-36.

${ }^{10}$ E. P. THOMPSON. Modes de domination et révolutions en Angleterre. In: Actes de la Recherche en Sciences Sociales, n 2-3/1976, pp. 133-151 (edição de J.-C.Chamboredon); E. HOBSBAWM. Sexe, symboles, vêtements et socialisme. In: Actes de la Recherche en Sciences Sociales, $n^{\circ} 23,1978$, pp. 2-18. Artigos de E. Hobsbawm, C. Schorske, R. Darnton, e nota bibliográfica sobre E. P. Thompson, falecido em agosto, no número comemorativo de Actes de la Recherche en Sciences Sociales, n 100, dezembro de 1993.

${ }^{11}$ Dialogue à propos de l'histoire culturelle. In: Actes de la Recherche en Sciences Sociales, $n^{\circ} 59$, sept. 1985 , pp. $86-93$

12 Posfácio incluído na coletânea organizada por Sergio MICELI. A Economia das Trocas Simbólicas. São Paulo: Perspectiva, 1974.

${ }^{13}$ Carlo GINZBURG. Prefácio a LORENZO VALLA. La Donation de Constantin. Paris: Belles Lettres, 1993, pp. ix-xxi.

${ }^{14}$ Michel de CERTEAU. "A operação historiográfica”. In: A escrita da história. Rio de Janeiro, Forense Universitária, 1982, pp. 65-119.

${ }^{15}$ Abdelmalek SAYAD. La double absence: des illusions de l'émigré aux souffrances de l'immigré. Paris: Seuil, 1999 e L'immigration ou les paradoxes de l'alterité. Bruxelles: De Boeck, 1991.

${ }^{16}$ Pierre BOURDIEU. Interventions, 1961-2001. In: Franck POUPEAU e Thierry DISCEPOLO (orgs.), Science sociale \& action politique. Marseille: Agone, 2002. Para o conjunto da obra de Bourdieu, ver Yvette DELSAUT e Marie-Christine RIVIÈRE. Bibliographie des travaux de Pierre Bourdieu, suivi d'un entretien sur l'esprit de la recherche. Paris: Le Temps des Cerises, 2002. 